\title{
The Glycine Receptor Deficiency of the Mutant Mouse Spastic: Evidence for Normal Glycine Receptor Structure and Localization
}

\author{
Cord-Michael Becker, Irmgard Hermans-Borgmeyer, Bertram Schmitt, and Heinrich Betz
}

Institut für Neurobiologie, ZMBH, Zentrum für Molekulare Biologie, Universität Heidelberg, Im Neuenheimer Feld 282, D-6900 Heidelberg, Federal Republic of Germany

Homozygotes of the mutant mouse spastic exhibit reduced binding of ${ }^{3} \mathrm{H}$-strychnine to homogenates from various regions of the CNS compared with unaffected littermates (White and Heller, 1982). Here we report evidence that the spastic mutation coincides with a reduced concentration and an unaltered structure of the glycine receptor in spinal cord. Scatchard analysis of ${ }^{3} \mathrm{H}$ strychnine binding revealed a single binding site with a $B_{\max }$ of $267 \pm 62 \mathrm{fmol} / \mathrm{mg}$ protein for spastic and of $864 \pm 220 \mathrm{fmol} /$ mg protein for control mice; no difference was found for the corresponding $K_{\mathrm{D}}$ values. Also, $K_{\mathrm{i}}$ values of glycine for ${ }^{3} \mathrm{H}$-strychnine binding and displacement of ${ }^{3} \mathrm{H}$-strychnine by $\beta$-alanine and taurine were indistinguishable for both preparations.

Photoaffinity labeling of synaptic membranes with ${ }^{3} \mathrm{H}$-strychnine identified an $M_{\mathrm{r}}=48,000$ polypeptide in both control and spastic mouse membranes. Tryptic digestion of these membranes produced radiolabeled peptide fragments of identical molecular weights, suggesting that the proteolytic cleavage sites around the antagonist binding site are conserved in the mutant glycine receptor protein. Glycine receptors from both control and mutant mice were purified by affinity chromatography on aminostrychnine agarose. SDS/PAGE revealed three polypeptides of $M_{\mathrm{r}}=48,000,58,000$, and 93,000 in both receptor preparations.

Monoclonal antibodies directed against different subunits of the glycine receptor were applied to an enzyme-linked immunosorbent assay. The same pattern of immunoreactivity was obtained for glycine receptor from spinal cord of spastic homozygotes, control mice, and rats, suggesting conservation of the antigenic epitopes in the mutant receptor. Immunofluorescence microscopy of spinal cord sections from spastic and control mice using these monoclonal antibodies revealed a patchy distribution of fluorescence on neurons and within the neuropil. Thus, the reduction of ${ }^{3} \mathrm{H}$-strychnine binding observed in the mutant mouse spastic may result from a regulatory, rather than a structural, effect of the mutation on glycine receptors.

Glycine is a major inhibitory neurotransmitter in spinal cord and other regions of the CNS (Aprison and Daly, 1978; Curtis et al., 1968; Werman et al., 1967). Binding of this amino acid to specific receptors increases the chloride conductance of the neuronal membrane and thus produces hyperpolarization, i.e., inhibition of the postsynaptic neuron. The alkaloid strychnine antagonizes glycine-mediated inhibition, and glycine-displace-

\footnotetext{
Received July 10, 1985; accepted Aug. 27, 1985.

This work was supported by the Deutsche Forschungsgemeinschaft, the Bundesministerium für Forschung und Technologie, and the Fonds der Chemischen Industrie. C.-M.B. is a fellow of the Boehringer-Ingelheim Foundation. We wish to thank Dr. B. Wiedenmann for performing the immunocytochemistry, C. Schröder for expert technical assistance, Drs. E. Gundelfinger and H. Rehm for critical reading of the manuscript, and $\mathrm{R}$. Franklin for help with its preparation.

Correspondence should be addressed to $\mathrm{H}$. Betz at the above address.

Copyright @ 1986 Society for Neuroscience $0270-6474 / 86 / 051358-07 \$ 02.00 / 0$
}

able ${ }^{3} \mathrm{H}$-strychnine binding is generally accepted as a reliable assay of the glycine receptor (Snyder and Bennett, 1976; Young and Snyder, 1973, 1974).

Recently, the glycine receptor from mammalian spinal cord was solubilized and purified by affinity chromatography (Graham et al., 1985; Pfeiffer and Betz, 1981; Pfeiffer et al., 1982). The purified receptor behaves as a glycoprotein with a molecular weight of $M_{\mathrm{r}}=246,000$, which contains three polypeptides of $M_{\mathrm{r}}=48,000,58,000$, and 93,000. Photoaffinity labeling with ${ }^{3} \mathrm{H}$-strychnine of both synaptic membranes and purified glycine receptor preparations (Graham et al., 1981, 1983, 1985; Pfeiffer et al., 1982) showed that the antagonist binding site of this receptor is located on the $M_{\mathrm{r}}=48,000$ polypeptide.

Homozygotes of the mutant mouse spastic are characterized by disturbed motor function, tremor, prolonged righting reflexes, and abnormal gait (Chai, 1961). In a recombination study, the mutation has been assigned to a single locus on chromosome 3 (Lane and Eicher, 1979). The nature of this recessive mutation and the product of the gene affected are not known. Preliminary morphological studies using light microscopy failed to detect structural alterations in the brain and spinal cord of the spastic mouse (Biscoe and Fry, 1982; Chai et al., 1962). However, electromyography showed a striking rescmblance of the spastic phenotype to sublethal strychnine intoxication of normal mice (Heller and Hallet, 1982). Furthermore, binding of ${ }^{3} \mathrm{H}$-strychnine to homogenates from various regions of the CNS of spastic homozygotes is drastically reduced (White and Heller, 1982). In contrast, binding of GABAergic receptor ligands such as benzodiazepines and muscimol is increased (Biscoe et al., 1981; White and Heller, 1982). The binding of other receptor ligands (White and Heller, 1982) and the activity of enzymes involved in the metabolism of GABA (Chatterjee and Hechtman, 1977) are not significantly affected. This has been interpreted as a compensatory elevation of GABA-mediated inhibition secondary to a defective glycine receptor function (White and Heller, 1982). Therefore, it was of interest to determine whether the spastic mutation represents an alteration of the binding affinity, concentration, and/or structure of the glycine receptor. Here, we report evidence that the spastic mutation affects the regulation, rather than the structure, of the glycine receptor protein.

\section{Materials and Methods}

\section{Materials}

${ }^{3} \mathrm{H}$-strychnine (specific activity $17.0 \mathrm{Ci} / \mathrm{mmol}$ ) was purchased from Amersham-Buchler (Braunschweig, FRG); glycine, $\beta$-alanine, taurine, serine, GABA, $o$-phenylene-diamine, polyethylene glycol 8000 , and egg yolk phosphatidylcholine (type X-E) were all from Sigma (Munich FRG). Triton X-100 was from Serva (Heidelberg, FRG); low-molecular-weight markers and soybean trypsin inhibitor were obtained from Bio-Rad (Munich, FRG). Trypsin treated with L-(tosylamido-2-phenyl)ethyl chloromethyl ketone (TPCK-trypsin) was from Worthington (Freehold, NJ). Microtiter plates were from Dynatech (Alexandria, VA). Rabbit 
anti-mouse immunoglobulins were from Dakopatts (Hamburg, FRG). Aminostrychnine agarose was synthesized as described (Pfeiffer et al., 1982).

\section{Animals}

Heterozygotes of the mutant mouse spastic were obtained from Jackson Laboratories (Bar Harbor, ME). Homozygotes were obtained by mating heterozygotic mice; occasionally, homozygotic male mice were also employed in the breeding. Unaffected littermates comprising both heterozygotes and homozygotic normal mice served as control animals.

\section{Preparation of crude synaptic membranes}

Spinal cord, medulla oblongata, and pons were rapidly removed from adult spastic mice and unaffected littermates, frozen in liquid nitrogen, and stored at $-70^{\circ} \mathrm{C}$. Crude synaptic membranes were prepared simultaneously from frozen tissue of spastic and control mice as previously described (Pfeiffer et al., 1982), except that the cell nuclei were removed by centrifugation at $1000 \times g$ for $5 \mathrm{~min}$.

\section{Solubilization and affinity chromatography of the glycine receptor from spinal cord of normal and spastic mice}

The glycine receptor was solubilized using the nonionic detergent Triton $\mathrm{X}-100$ as previously described (Pfeiffer and Betz, 1981) with the following modifications: Crude synaptic membranes were incubated in 2.5 $\mathrm{mm}$ iodoacetamide for $5 \mathrm{~min}$ and then solubilized with $3 \%(\mathrm{wt} / \mathrm{vol})$ Triton X-100 in $25 \mathrm{~mm}$ potassium phosphate, $\mathrm{pH} 7.4$, containing $5 \mathrm{~mm}$ neutralized EDTA, 5 mM neutralized EGTA, $5 \mathrm{~mm}$ dithiothreitol, and a mixture of protease inhibitors (Pfeiffer et al., 1982). The membranes were kept on ice and stirred for $1 \mathrm{hr}$. After centrifugation at 150,000 $\times$ $g$ for $1 \mathrm{hr}$, the glycine receptors of normal and spastic mice were purified from the detergent extracts by affinity chromatography on aminostrychnine-agarose columns (Pfeiffer et al., 1982).

\section{Strychnine binding assays}

Membrane-bound receptor. ${ }^{3} \mathrm{H}$-strychnine binding to crude synaptic mcmbrancs was determined as previously described (Pfeiffer and Betz, 1981). For small samples, a modified assay was used: Samples containing $80-100 \mu \mathrm{g}$ membrane protein in $80 \mu \mathrm{l}$ of $25 \mathrm{~mm}$ potassium phosphate, $\mathrm{pH} 7.4$, and $200 \mathrm{~mm} \mathrm{KCl}$ were incubated on ice with ${ }^{3} \mathrm{H}$-strychnine and futher additions as indicated. After $60 \mathrm{~min}$, the samples were pipetted onto a $13 \mathrm{~mm}$ diameter Whatman GF/C-filter that had been sequentially presoaked in $0.1 \mathrm{mg} / \mathrm{ml}$ polylysine and $0.5 \%(\mathrm{wt} / \mathrm{vol}) \mathrm{BSA}$ in PBS. The filters were washed once with $4 \mathrm{ml}$ of ice-cold $25 \mathrm{~mm}$

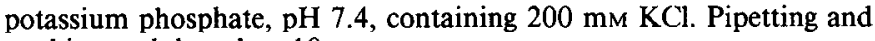
washing took less than $10 \mathrm{sec}$.

Solubilized receptor. ${ }^{3} \mathrm{H}$-strychnine binding was determined by polyethylene glycol precipitation (Pfeiffer and Betz, 1981). All binding assays were performed in triplicate.

\section{Determination of binding constants}

Equilibrium dissociation constants $\left(K_{\mathrm{D}}\right)$ of ${ }^{3} \mathrm{H}$-strychnine binding were determined as described by Young and Snyder (1974). Inhibition constants $\left(K_{\mathrm{i}}\right)$ for the agonist glycine were determined by inhibition of ${ }^{3} \mathrm{H}$ strychnine binding. Owing to high background, it was not feasible to perform the competition experiments at a saturating concentration of ${ }^{3} \mathrm{H}$-strychnine. Routinely, $24 \mathrm{~nm}{ }^{3} \mathrm{H}$-strychnine was employed, which corresponds to an approximately $75 \%$ saturation of all binding sites. Therefore, free receptor sites had to be considered. According to Maelicke et al. (1977), the fraction $(f)$ of receptor occupied by strychnine is given by

$$
f=\frac{(R S)}{R_{\mathrm{t}}}=\frac{1}{1+K_{\mathrm{D}} / S\left(1+I^{n /} K_{\mathrm{i}}^{n}\right)}
$$

where $R_{1}$ is the total number of binding sites; $(R S)$, the number of receptor- ${ }^{3} \mathrm{H}$-strychnine complexes; $K_{\mathrm{D}}$, the dissociation constant for ${ }^{3} \mathrm{H}-$ strychnine; $K_{\mathrm{i}}$, the inhibition constant for glycine; $S$, the concentration of ${ }^{3} \mathrm{H}$-strychnine; $I$, the concentration of competing ligand; and $n$, the number of binding sites of glycine per binding site of ${ }^{3} \mathrm{H}$-strychnine.

This equation can be rewritten

$$
\frac{I^{n}}{K_{\mathrm{i}}^{n}}=\frac{S}{K_{\mathrm{D}}}\left(\frac{R_{\mathrm{t}}}{(R S)}-1\right)-1
$$

and transformed into

$$
\log \left[S / K_{\mathrm{D}}\left(R_{\mathrm{t}} /(R S)-1\right)-1\right]=n \log I-n \log K_{\mathrm{i}}
$$

Plotting $\log \left[S / K_{\mathrm{D}}\left(R_{\mathrm{t}} /(R S)-1\right)-1\right]$ on the ordinate versus $\log I$ on the abscissa produces a straight line that yields a slope of $n$. $K_{\mathrm{i}}$ values can be determined from the intercept at the abscissa. With $n=1$, the equation simplifies to a linear form:

$$
S / K_{\mathrm{D}}\left[R_{\mathrm{t}} /(R S)-1\right]-1=I / K_{\mathrm{i}}
$$

As will be shown, $n$ was close to 1.0 for glycine displacement of ${ }^{3} \mathrm{H}$ strychnine binding. Therefore, the linear form of the equation was used here to determine the $K_{\mathrm{i}}$ values.

\section{Gel electrophoresis}

All samples were concentrated by protein precipitation according to Wessel and Flügge (1984). The resulting pellet was subjected to SDS/ PAGE in 10\% slab gels (Laemmli, 1970). Protein bands were visualized by the silver-staining method of Oakley et al. (1980).

\section{Photoaffinity labeling}

Photoaffinity labeling of membranes with ${ }^{3} \mathrm{H}$-strychnine was performed as previously described (Graham et al., 1981, 1983). For trypsin digestion, membranes were collected by centrifugation at $50,000 \times g$ for 15 min at $4^{\circ} \mathrm{C}$ and resuspended in $25 \mathrm{~mm}$ potassium phosphate buffer, $\mathrm{pH}$ 7.4 , at a protein concentration of $2.7 \mathrm{mg} / \mathrm{ml}$. Freshly dissolved TPCK trypsin $(75 \mu \mathrm{l})$ at concentrations of 0,10 , and $100 \mu \mathrm{g} / \mathrm{ml}$ was added to $300 \mu \mathrm{l}$ of membrane suspension. After $30 \mathrm{~min}$ at room temperature, the reaction was terminated by addition of $25 \mu$ l soybean trypsin inhibitor $(1 \mathrm{mg} / \mathrm{ml}$ ), and the protein was precipitated (Wessel and Flügge, 1984). SDS/PAGE and fluorography were performed as described (Graham et al., 1981, 1983).

\section{Enzyme-linked immunosorbent assay}

Affinity-purified glycine receptor from spinal cord of rat, normal, and spastic mice was coated at $4^{\circ} \mathrm{C}$ into polystyrene microtiter plates. To each well, $7.5-9.5 \mathrm{fmol}$ of purified receptor diluted with $0.1 \mathrm{M}$ sodium bicarbonate buffer, $\mathrm{pH} 9.0$, containing $0.1 \%(\mathrm{wt} / \mathrm{vol})$ Triton X-100 was added in a volume of $100 \mu \mathrm{l}$. After overnight incubation at $4^{\circ} \mathrm{C}$, the plates were washed $3 \times$ with PBS containing $0.1 \%(w t / v o l)$ Triton $X$ 100 , and free binding sites were blocked with $1 \%$ (wt/vol) BSA in PBS. Monoclonal antibodies raised against glycine receptor from rat spinal cord (Pfeiffer et al., 1984) were then applied to wells after a 1:100 dilution in PBS containing $0.1 \%(\mathrm{wt} / \mathrm{vol}) \mathrm{BSA}$. The microtiter plates were incubated at $37^{\circ} \mathrm{C}$ for $2 \mathrm{hr}$, washed again, and rabbit anti-mouse immunoglobulin coupled to HRP was added at a dilution of 1:1000 in PBS containing $0.1 \%$ (wt/vol) BSA. After incubation for $1 \mathrm{hr}$ and five washes, a substrate solution containing $0.4 \mathrm{mg} / \mathrm{ml}$ ortho-phenylene diamine, $0.003 \% \mathrm{H}_{2} \mathrm{O}_{2}$ dissolved in $0.1 \mathrm{M}$ citrate phosphate buffer, pH 5.0 , was added. The reaction was terminated after $5-10 \mathrm{~min}$ by adding $20 \mu \mathrm{l} 3 \mathrm{~N}$ $\mathrm{H}_{2} \mathrm{SO}_{4}$ to each well. Enzyme-linked immunosorbent assay (ELISA) reactions were quantitated by photometry at $492 \mathrm{~nm}$.

\section{Immunofluorescence microscopy}

Immunofluorescence microscopy of spinal cord tissue was performed as described by Wiedenmann and Franke (1985) using the monoclonal antibodies GlyR 5a and 7a (Pfeiffer et al., 1984).

\section{Results and Discussion}

\section{${ }^{3} H$-strychnine binding}

The binding of ${ }^{3} \mathrm{H}$-strychnine to crude snyaptic membranes prepared from spinal cord of both control and spastic mice was studied at concentrations ranging from 0.26 to $29.4 \mathrm{~nm}$. In the filter assay used, the nonspecific binding of ${ }^{3} \mathrm{H}$-strychnine to membranes determined in the presence of $10 \mathrm{~mm}$ glycine accounted for $5-30 \%$ and $13-46 \%$ of the total binding for normal and mutant mice, respectively. Scatchard analysis of ${ }^{3} \mathrm{H}$-strychnine binding (Fig. 1) revealed a single class of binding sites with dissociation constants $\left(K_{\mathrm{D}}\right)$ of $7.68 \pm 0.95 \mathrm{nM}$ for spastic mice and $7.46 \pm 0.85 \mathrm{~nm}$ for control mice. The total number of binding sites $\left(B_{\max }\right)$ was reduced from $864 \pm 220 \mathrm{fmol} / \mathrm{mg}$ protein for spinal cord membranes from control mice to $267 \pm 62$ 


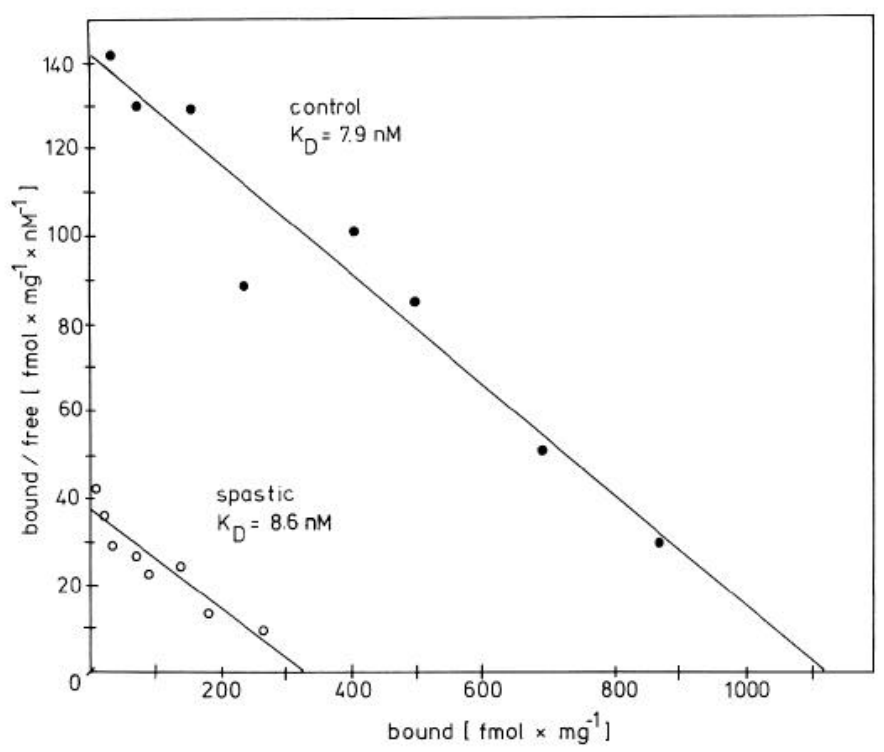

Figure 1. Scatchard analysis of ${ }^{3} \mathrm{H}$-strychnine binding to spinal cord membranes from control mice $(\bullet)$ and spastic homozygotes $(O)$. In the experiment shown, membranes were present at a protein concentration of $1.25 \mathrm{mg} / \mathrm{ml}$ and $0.95 \mathrm{mg} / \mathrm{ml}$ for preparations from normal and spastic mice, respectively. The total number of binding sites was $1118 \mathrm{fmol} /$ $\mathrm{mg}$ for control animals and $324 \mathrm{fmol} / \mathrm{mg}$ for spastic animals. This experiment was performed $3 \times$. The mean values of all three experiments are given in the text.

$\mathrm{fmol} / \mathrm{mg}$ protein for preparations from spastic homozygotes (mean of three independent experiments). With normal mice the total number of binding sites for membrane preparations was thus in the range of previous observations based on filter assay for rat (Pfeiffer et al., 1982) and pig (Graham et al., 1985) spinal cord membranes. Determination by centrifugation assay generally leads to higher values of the total number of binding sites (Young and Snyder, 1974). This discrepancy results from a nonquantitative but proportional recovery of ${ }^{3} \mathrm{H}$-strychnine binding sites by the filter assay which, in a previous study, was estimated to account for about $50 \%$ of the number of binding sites determined by a centrifugation assay (Pfeiffer et al., 1982). In contrast to control mice, crude synaptic membranes from spinal cord of spastic mice exhibited a $>3$-fold reduction of the total number of ${ }^{3} \mathrm{H}$-strychnine binding sites that was not accompanied by changes in binding affinity.

Glycine inhibited the binding of ${ }^{3} \mathrm{H}$-strychnine to crude synaptic membranes from homozygotic mutants and control mice

Table 1. Inhibition of ${ }^{3} \mathrm{H}$-strychnine binding to synaptic membranes by different amino acids

Inhibition of specific binding (\%)

\begin{tabular}{llc}
\cline { 2 - 3 } Ligand & Control & Spastic \\
\hline Glycine $(85 \mu \mathrm{M})$ & $41.9 \pm 1.9$ & $42.8 \pm 4.8$ \\
$\beta$-Alanine $(116 \mu \mathrm{M})$ & $32.0 \pm 4.7$ & $32.7 \pm 2.1$ \\
Taurine $(445 \mu \mathrm{M})$ & $54.2 \pm 1.2$ & $54.7 \pm 1.3$ \\
GABA $(1 \mathrm{mM})$ & $3.6 \pm 1.4$ & $0.1 \pm 0.05$ \\
Serine $(1 \mathrm{mM})$ & $9.1 \pm 5.1$ & $8.6 \pm 8.6$
\end{tabular}

Crude synaptic membranes prepared from control mice and spastic homozygotes were incubated at $4^{\circ} \mathrm{C}$ in the presence of $24 \mathrm{nM}{ }^{3} \mathrm{H}$-strychnine and amino acids as indicated. After $45 \mathrm{~min}$, specific ${ }^{3} \mathrm{H}$-strychnine binding was determined by filter assay. Results are expressed as the percentage inhibition of specific ${ }^{3} \mathrm{H}$-strychnine binding compared with values obtained in the absence of amino acid. The values represent the mean \pm SEM of two independent experiments.

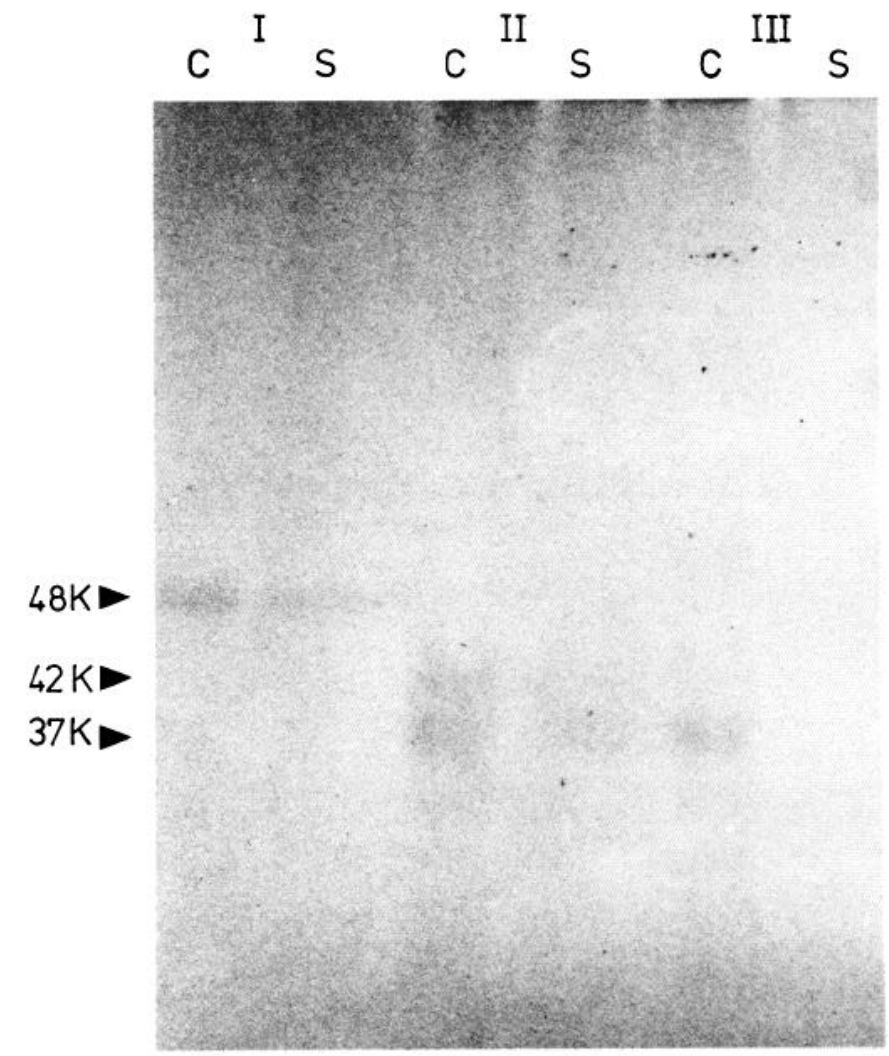

Figure 2. Fluorogram of membranes photoaffinity-labeled with ${ }^{3} \mathrm{H}-$ strychnine. Membranes from spinal cord of phenotypically normal $(C)$ and spastic mice $(S)$ were illuminated in the presence of $24 \mathrm{~nm}{ }^{3} \mathrm{H}-$ strychnine. Aliquots of membrane suspension $(300 \mu \mathrm{l} ; 2.7 \mathrm{mg} / \mathrm{ml})$ were then treated with $75 \mu \mathrm{l}$ of trypsin at concentrations of (I) 0 , (II) 10 , and (III) $100 \mu \mathrm{g} / \mathrm{ml}$ as described under Materials and Methods, and electrophoresed on a $10 \%$ SDS-polyacrylamide gel. To correct for differences in the number of strychnine binding sites, $0.22 \mathrm{mg}$ of illuminated membrane protein from control mice and $0.86 \mathrm{mg}$ of protein from spastic homozygotes were applied to the lanes marked $(C)$ and $(S)$, respectively.

equally (Table 1). The molar ratio of glycine bound per binding site of ${ }^{3} \mathrm{H}$-strychnine was determined by the logarithmic plot given under Materials and Methods. Values of $n=1.04 \pm 0.15$ and $n=0.99 \pm 0.17$ were calculated for membranes from spinal cord of spastic and normal mice, respectively. Assuming one glycine molecule bound per ${ }^{3} \mathrm{H}$-strychnine binding site, the inhibition constants $\left(K_{\mathrm{i}}\right)$ of glycine were calculated to be $22.4 \pm$ 2.4 and $19.0 \pm 1.7 \mu \mathrm{M}$ for membranes of spastic and control mice, respectively.

The binding of ${ }^{3} \mathrm{H}$-strychnine to both membrane preparations was inhibited by the glycinergic agonists $\beta$-alanine and taurine to a similar extent (Table 1); GABA and serine, in contrast, had little effect. Owing to limited amounts of membrane from mutant mice, we did not determine $K_{\mathrm{i}}$ values for these amino acids. However, the data shown clearly demonstrate that the affinity and specificity for glycinergic ligands of the spastic mouse receptor were not significantly different from that of the control mice.

\section{Photoaffinity labeling}

Photoaffinity-labeling experiments with ${ }^{3} \mathrm{H}$-strychnine showed that on UV illumination radioactivity was incorporated into a polypeptide of $M_{\mathrm{r}}=48,000$ of membrane preparations from both spastic and control mice (Fig. 2). The addition of $10 \mathrm{~mm}$ glycine prevented the labeling of this polypeptide (not shown). 


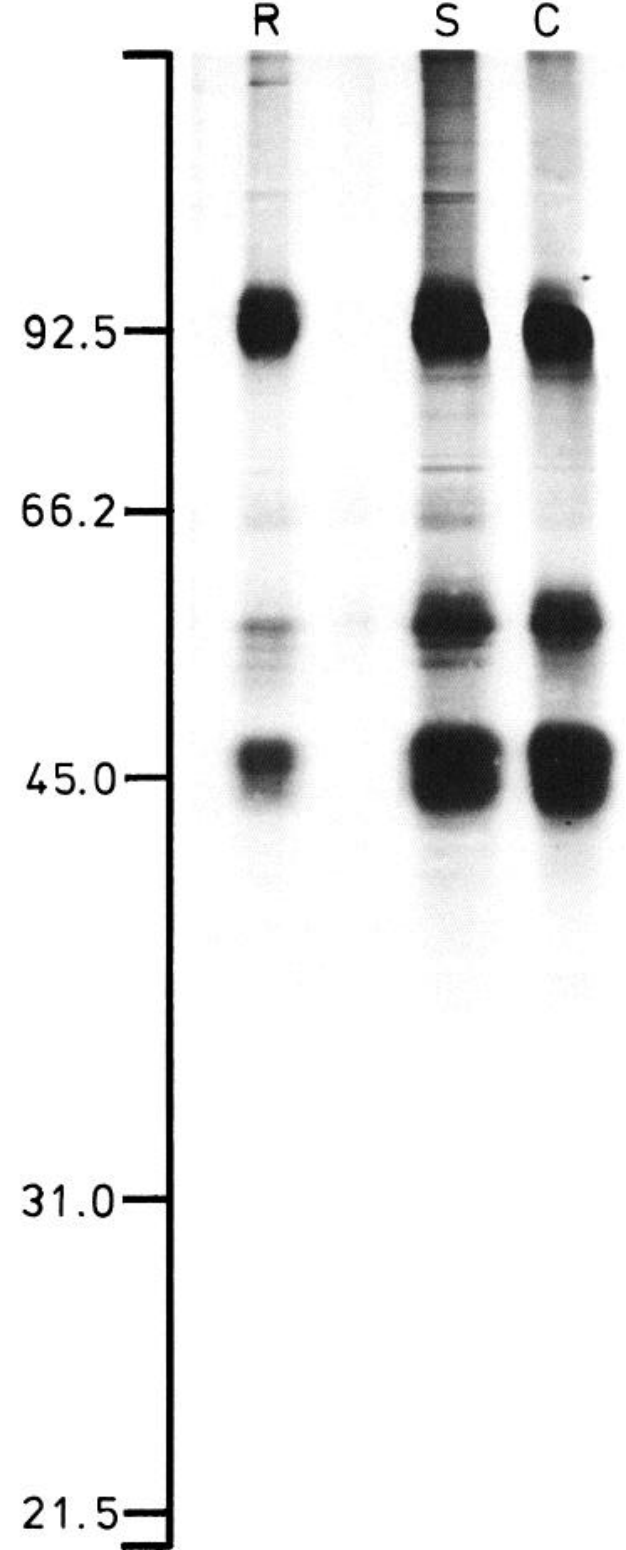

Figure 3. SDS/PAGE of purified glycine receptors. ${ }^{3} \mathrm{H}$-strychnine binding sites from spinal cord were solubilized and subjected to affinity chromatography on an aminostrychnine agarose column. Column eluates containing equal amounts (about $1.4 \mathrm{pmol}$ ) of glycine receptor from spinal cord of rat (lane R), spastic (lane S), and control mice (lane C) were subjected to SDS/PAGE. Positions of the molecular-weight markers phosphorylase B $\left(M_{\mathrm{r}}=92,500\right)$, BSA $\left(M_{\mathrm{r}}=66,200\right)$, ovalbumin $\left(M_{\mathrm{r}}=45,000\right)$, carbonic anhydrase $\left(M_{\mathrm{r}}=31,000\right)$, and soybean trypsin inhibitor $\left(M_{\mathrm{r}}=21,500\right)$ are indicated.

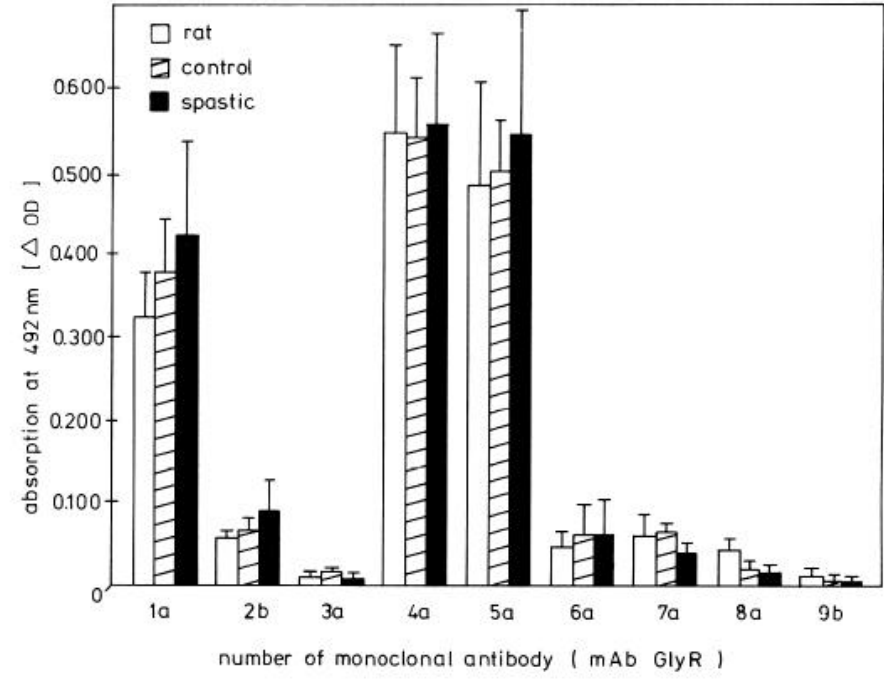

Figure 4. Antibody binding to purified glycine receptor from rat, control mouse, and spastic mutant. Equal amounts of glycine receptor purified from spinal cord of rat (open bars), control (hatched bars), and spastic (black bars) mice were used in an ELISA with monoclonal antibodies GlyR mab la to $9 \mathrm{~b}$ as described under Materials and Methods.

For rat and pig, ${ }^{3} \mathrm{H}$-strychnine binding has been shown to occur at the $M_{\mathrm{r}}=48,000$ subunit of the glycine receptor (Graham et al., 1981, 1985; Pfeiffer et al., 1982). Thus, a polypeptide of identical molecular weight also binds ${ }^{3} \mathrm{H}$-strychnine in mouse spinal cord membranes. Tryptic digestion of the ${ }^{3} \mathrm{H}$-strychninelabeled membranes produced two major fragments of $M_{\mathrm{r}}=$ 42,000 and 37,000 for both spastic and phenotypically normal mice, as has been found before for other species (Graham et al., 1983, 1985). Therefore, the tryptic cleavage sites at the ${ }^{3} \mathrm{H}$-strychnine binding site of the $M_{\mathrm{r}}=48,000$ subunit were conserved in the spastic glycine receptor.

\section{Affinity purification}

Detergent extracts were prepared from crude synaptic membranes using Triton X-100. The glycine receptor was then purified from the detergent extracts by affinity chromatography on aminostrychnine-agarose columns. The number of glycine receptor sites recovered from the columns ranged from 10 to $15 \%$ without significant differences between the two membrane preparations. Also, throughout the experiments no alteration in the ratio of receptor sites between spastic and control mice was seen (Table 2). This suggests that no cryptic ligand binding sites (Rehm and Betz, 1981) were present in membranes from spastic mice.

The column eluates were subjected to electrophoresis on $10 \%$ SDS-polyacrylamide gels. Silver staining revealed three major protein bands of $48,000,58,000$, and 93,000 molecular weight

Table 2. Purification of the glycine receptor from detergent extracts of synaptic membranes from spastic and control mice

\begin{tabular}{lrrr} 
& \multicolumn{2}{l}{${ }^{3} \mathrm{H}$-strychnine bound $(\mathrm{pmol} / \mathrm{gm})$} & \\
\cline { 2 - 3 } Purification & \multicolumn{1}{l}{ Control } & Spastic & Spastic/control \\
\hline Crude synaptic membranes & $40.25 \pm 3.08$ & $8.13 \pm 0.52$ & $0.20 \pm 0.02$ \\
Triton-X-100 extract & $22.67 \pm 2.49$ & $6.42 \pm 0.87$ & $0.28 \pm 0.05$ \\
Column eluate & $3.38 \pm 1.90$ & $0.74 \pm 0.14$ & $0.22 \pm 0.13$
\end{tabular}

The number of ${ }^{3} \mathrm{H}$-strychnine binding sites recovered per gram fresh wet weight of spinal cord tissue is indicated for the different steps of glycine receptor purification. The values are the means \pm SEM of three independent experiments. For each purification step, the ratio spastic to control of ${ }^{3} \mathrm{H}$-strychnine binding sites was calculated. 
Figure 5. Immunofluorescence staining by mab GlyR 7a of sections from thoracic segments of spinal cord. Buttonlike patches were stained on the cellular membrane of neurons in the anterior horn and within the neuropil of spastic $(a)$ and control mice $(b)$. Scale bar, $10 \mu \mathrm{m}$.
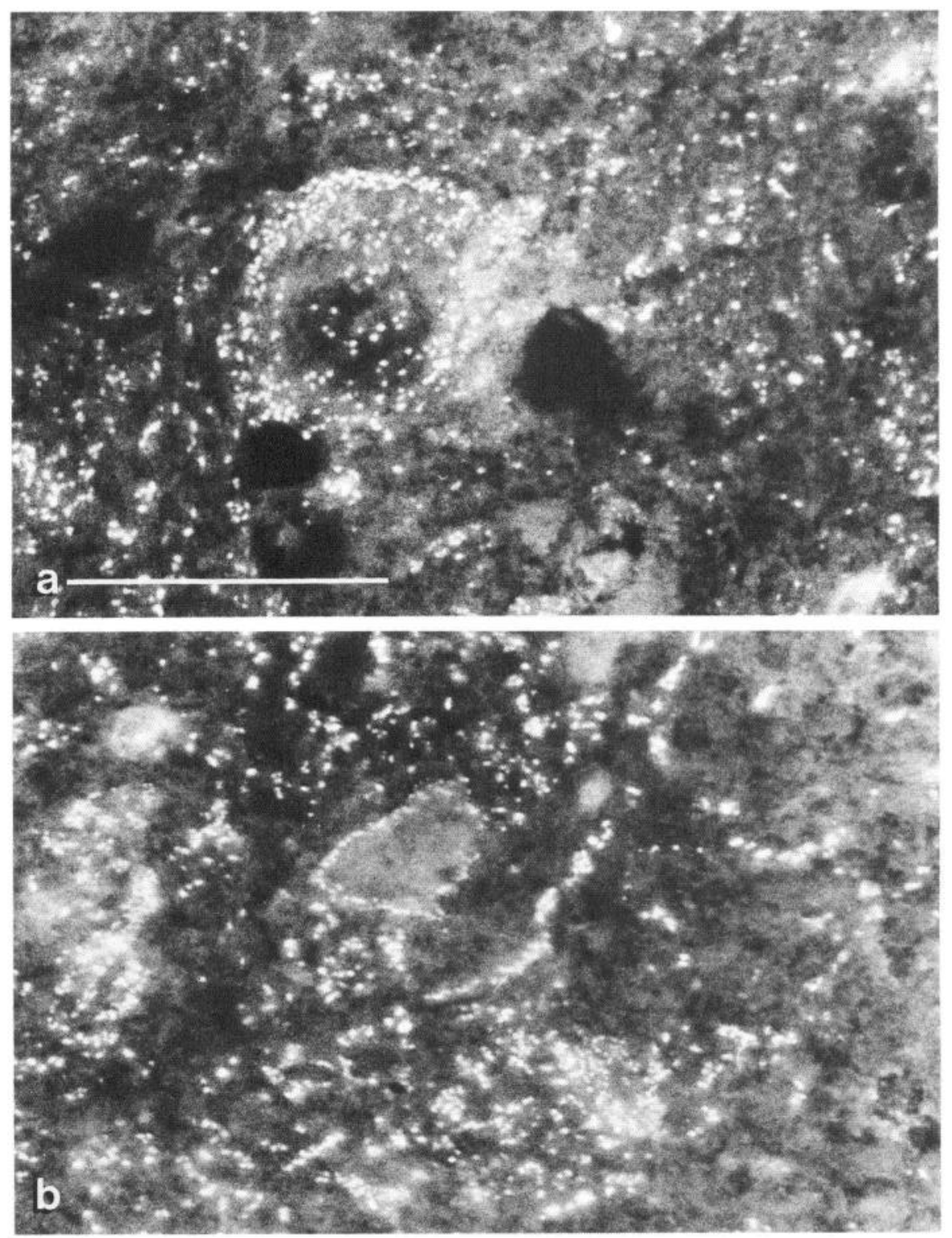

for both the control and the mutant receptor (Fig. 3). The same polypeptide pattern has previously been found with glycine receptor from other species (Graham et al., 1985; Pfeiffer et al., 1982). Occasionally, another polypeptide of $M_{\mathrm{r}}=66,000$ was seen, which disappeared on preincubation of membranes with $2.5 \mathrm{~mm}$ iodoacetamide before solubilization. In agreement with findings of Graham et al. (1985), this polypeptide band may represent a proteolytic fragment of the $M_{\mathrm{r}}=93,000$ polypeptide (see also Betz et al., 1985). Thus, conservation of the polypeptide pattern of the glycine receptor in spastic mutants excludes major alterations of individual receptor polypeptides.

\section{Immunological profile of purified glycine receptor}

Monoclonal antibodies raised previously against the glycine receptor of rat spinal cord (Pfeiffer et al., 1984) were used in an ELISA (Engvall and Perlmann, 1971) in order to compare the immunological properties of normal and mutant mouse receptors. Purified receptor was coated to microtiter plates and reacted with monoclonal antibodies. Figure 4 presents the immunological profiles of glycine receptors from rat and phenotypically normal and homozygotic mutant mouse spinal cord as revealed by ELISA with nine different monoclonal an- tibodies. No significant differences in immunoreactivity were detected between the three glycine receptor preparations. Using immunoblots, the $M_{\mathrm{r}}=48,000$ polypeptide of the rat glycine receptor has been shown to bind monoclonal antibodies $1 \mathrm{a}, 2 \mathrm{a}$, and $4 \mathrm{a}$ (Pfeiffer et al., 1984). The latter also recognizes the $M_{\mathrm{r}}=$ 58,000 subunit, whereas monoclonal antibodies $5 \mathrm{a}, 7 \mathrm{a}$, and $9 \mathrm{~b}$ detect epitopes present on the $M_{\mathrm{r}}=93,000$ subunit of the glycine receptor. Although the ELISA exhibited considerable differences in reaction intensity for the individual antibodies, comparative results for glycine receptors purified from normal and spastic mice were indistinguishable. Control experiments showed that color development of the ELISA peroxidase reaction was proportional to the amount of glycine receptor coated within the range used in our experiments (not shown).

The immunological profile obtained by ELISA of the mouse glycine receptor demonstrates that the epitopes detected by our monoclonal antibodies against different polypeptides of the glycine receptor from rat spinal cord are also present in the mouse. Furthermore, the corresponding epitopes are present in apparently unaltered ratios, which indicates that the subunit stoichiometry of the glycine receptor subunits has been conserved in the spastic mouse. 


\section{Immunofluorescence microscopy}

Preliminary studies on the neuroanatomy of the spastic mouse using light microscopy (Biscoe and Fry, 1982; Chai et al., 1962) failed to detect structural abnormalities in the nervous system of the spastic mouse. Therefore, it was of interest to study the localization of the glycine receptor by immunofluorescence microscopy in sections of mouse spinal cord. Immunofluorescent staining using monoclonal antibodies 5a (not shown) and 7a (Fig. 5) showed the same patchy distribution of fluorescence on neurons and within the neuropil of anterior and posterior horn of both normal and spastic mice. Also, the density of these patches was similar in both preparations. Triller et al. (1985) have demonstrated that this immunoreaction codistributes with glycinergic synapses. We therefore conclude that homozygotic mutants possess glycine receptors in the same regions of the spinal cord as their unaffected littermates, and that the reduction in glycine receptor number detected by ${ }^{3} \mathrm{H}$-strychnine binding is not due to a loss of glycinergic snyapses. These data further confirm previous conclusions (Biscoe and Fry, 1982; Chai et al., 1962) that the phenotype of the spastic mutant does not result from malformation or hypoplasia of a particular structure or cell type in the nervous system, as is the case for cerebellar mutants exhibiting altered neurotransmitter receptor binding (Skolnick et al., 1979).

\section{Conclusion}

Our data show that the ligand affinity and pharmacology of the glycine receptor from spastic homozygotes is indistinguishable from that of phenotypically normal control animals. This result supports the view that the spastic mutation does not alter the binding characteristics of the glycine receptor. Therefore, major mutational changes in receptor structure appear unlikely for functional domains at or close to the ligand binding sites of the spastic glycine receptor.

For the serum low-density lipoprotein (LDL) receptor, a mutation with a reduced molecular weight has been described (Lehrmann et al., 1985). This mutation causes reduced incorporation of receptor into the plasma membrane and thus affects receptor-mediated endocytosis. However, all polypeptides of the glycine receptor were present in spastic homozygotes with molecular weights identical to that of unaffected control mice and of two other species (Graham et al., 1985; Pfeiffer et al., 1982). Also, the tryptic cleavage sites of the ${ }^{3} \mathrm{I}$-strychnine binding polypeptide and the antigenic epitopes recognized by different monoclonal antibodies against the rat glycine receptor all were conserved in the spastic receptor protein. For the LDL receptor, antibody techniques have revealed structural alterations in hypcrlipidemic paticnts (Tolleshaug ct al., 1983). Wc therefore conclude that the glycine receptor deficiency of the spastic mutant is not caused by major deletions, changes in subunit composition, loss of antigenic sites defined by our monoclonal antibodies, or alterations at or close to the ligand binding sites of the mutant receptor protein. It may be noted, however, that at present minor changes in the receptor primary structure cannot be totally excluded. A more likely interpretation, however, is that the spastic mutation affects the regulation rather than the structure of the glycine receptor protein. This view receives additional support from our still preliminary immunocytochemical data. The latter suggest that glycinergic synapses in the spastic spinal cord contain less glycine receptor protein than those of control animals. Whether the reduced receptor number results from a reduced rate of receptor synthesis and/or assembly into the postsynaptic membrane (Lehrmann et al., 1985) or from an increased rate of receptor degradation (Drachman et al., 1978) remains to be determined. Whatever the mechanism, further analysis of the spastic mutation should provide a promising route toward a better un- derstanding of the regulation of chemosensitivity in the mammalian CNS.

During the preparation of this manuscript, a recent report of White (1985) came to our attention. This paper reports a slightly lowered affinity for ${ }^{3} \mathrm{H}$-strychnine binding to membranes from spinal cord of spastic mice, which accounts for an approximately $25 \%$ increase in $K_{\mathrm{D}}$. Also, binding to the spastic glycine receptor of glycine, $\beta$-alanine, and taurine was found to occur with reduced affinity. The reasons for the discrepancy between these findings and ours are not clear. It is possible that the different assay conditions used may have contributed to minor deviations of the determined binding affinities.

\section{References}

Aprison, M. H., and E. C. Daly (1978) Biochemical aspects of transmission at inhibitory synapses: The role of glycine. Adv. Neurochem. 3: 203-294.

Betz, H., G. Grenningloh, and B. Schmitt (1985) The glycine receptor of rat spinal cord: Progress in the investigation of a neuronal ion channel protein. In Molecular Basis of Nerve Activity, J. P. Changeux, F. Hucho, A. Maelicke, and E. Neumann, eds., pp. 263-272, de Gruyter, Berlin.

Biscoe, T. J., and J. P. Fry (1982) Some pharmacological studies on the spastic mouse. Br. J. Pharmacol. 75: 23-35.

Biscoe, T. J., J. P. Fry, J. L. Martin, and C. Rickets (1981) Binding of GABA and benzodiazepine receptor ligands in the spinal cord of the spastic mouse. J. Physiol. (Lond.) 317: 32P-33P.

Chai, C. K. (1961) Hereditary spasticity in mice. J. Hered. 52: 241243.

Chai, C. K., E. Roberts, and R. L. Sidman (1962) Influence of aminooxyacetic acid, a $\gamma$-aminobutyrate transaminase inhibitor, on hereditary spastic defect in the mouse. Proc. Soc. Exp. Biol. Med. 109: 491-495.

Chatterjee, S., and P. Hechtman (1977) $\gamma$-Aminobutyric acid metabolism in brain homogenates of the spastic mouse. Biochem. Genet. 15: 147-151.

Curtis, D. R., L. Hösli, and G. A. R. Johnston (1968) A pharmacological study of the depression of spinal neurones by glycine and related amino acids. Exp. Brain Res. 6: 1-18.

Drachman, D. B., C. W. Angus, R. N. Adams, and J. Kao (1978) Effect of myasthenic patients' immunoglobulin on acetylcholine receptor turnover: Selectivity of degradation process. Proc. Natl. Acad. Sci. USA 75: 3422-3426.

Engvall, E., and P. Perlmann (1971) Enzyme-linked immunosorbent assay (ELISA). Quantitative assay of immunoglobulin G. Immunochemistry $8: 871-874$.

Graham, D., F. Pfeiffer, and H. Betz (1981) UV light-induced crosslinking of strychnine to the glycine receptor of rat spinal cord membranes. Biochem. Biophys. Res. Commun. 102: 1330-1335.

Graham, D., F. Pfeiffer, and H. Betz (1983) Photoaffinity labelling of the glycine receptor of rat spinal cord. Eur. J. Biochem. 131: 519525.

Graham, D., F. Pfeiffer, R. Simler, and H. Betz (1985) Purification and characterization of the glycine receptor of pig spinal cord. Biochemistry 24: 990-994.

Heller, A. H., and M. Hallet (1982) Electrophysiological studies with the spastic mutant mouse. Brain Res. 234: 299-308.

Laemmli, U. K. (1970) Cleavage of structural proteins during the assembly of the head of bacteriophage T4. Nature 227: 680-685.

Lane, P. W., and E. M. Eicher (1979) Gene order in linkage group XVI of the house mouse. J. Hered. 70: 239-244.

Lehrmann, M. A., W. J. Schneider, T. C. Südhof, M. S. Brown, J. L. Goldstein, and D. W. Russell (1985) Mutation in LDL receptor: Alu-Alu recombination deletes exons encoding transmembrane and cytoplasmic domains. Science 227: 140-146.

Maelicke, A., B. W. Fulpius, R. P. Klett, and E. Reich (1977) Acetylcholine receptor. Responses to drus binding. J. Biol. Chem. 252: 4811-4830.

Oakley, B. R., D. R. Kirsch, and N. R. Morris (1980) A simplified ultrasensitive silver stain for detecting proteins in polyacrylamide gels. Anal. Biochem. 105: 316-363.

Pfeiffer, F., and H. Betz (1981) Solubilization of the glycine receptor from rat spinal cord. Brain Res. 226: 273-279.

Pfeiffer, F., D. Graham, and H. Betz (1982) Purification by affinity 
chromatography of the glycine receptor of rat spinal cord. J. Biol. Chem. 257: 9389-9393.

Pfeiffer, F., R. Simler, G. Grenningloh, and H. Betz (1984) Monoclonal antibodies and peptide mapping reveal structural similarities between the subunits of the glycine receptor of rat spinal cord. Proc. Natl. Acad. Sci. USA 81: 7224-7227.

Rehm, H., and H. Betz (1981) Unmasking of cryptic binding sites for $\alpha$-bungarotoxin in membrane fractions from chick rctina. Biochem. Biophys. Res. Commun. 102: 1385-1392.

Skolnick, P., P. J. Syapin, B. A. Panghi, and S. M. Paul (1979) Reduction in benzodiazepine receptors associated with Purkinje cell degeneration in "nervous" mutant mice. Nature 277: 397-399.

Snyder, S. H., and J. P. Bennett (1976) Neurotransmitter receptors in the brain: Biochemical identification. Annu. Rev. Physiol. 38: 153175.

Tolleshaug, H., K. K. Hobgood, M. S. Brown, and J. L. Goldstein (1983) The LDL receptor locus in famial hypercholesterolemia. Multiple mutations disrupt transport and processing of a membrane receptor. Cell 32: 941-951.

Triller, A., A. Cluzeaud, F. Pfeiffer, H. Betz, and H. Korn (1985) Distribution of glycine receptors at central synapses: An immunoelectron-microscopy study. J. Cell Biol. 101: 683-688.
Werman, R., R. A. Davidoff, and M. H. Aprison (1967) Inhibition of motoneurones by iontophoresis of glycine. Nature 214: 681-683.

Wessel, D., and U. J. Flügge (1984) A method for the quantitative recovery of protein in dilute solution in the presence of detergents and lipids. Anal. Biochem. 138: 131-143.

White, W. F. (1985) The glycine receptor in the mutant mouse spastic (spa): Strychnine binding characteristics and pharmacology. Brain Res. 329: 1-6.

White, W. F., and A. H. Heller (1982) Glycine receptor alteration in the mutant mouse spastic. Nature 298: 655-657.

Wiedenmann, B., and W. W. Franke (1985) Identification and localization of an integral membrane protein of Mr 38,000 (Synaptophysin) characteristic of presynaptic vesicles. Cell 41: 1017-1028.

Young, A. B., and S. H. Snyder (1973) Strychnine binding associated with glycine receptors of the central nervous system. Proc. Natl. Acad. Sci. USA 70: 2832-2836.

Young, A. B., and S. H. Snyder (1974) Strychnine binding in rat spinal cord membranes associated with the synaptic glycine receptor: Cooperativity of glycine interactions. Mol. Pharmacol. 10: 790-809. 